\title{
Study of pectinase production in submerged fermentation using different strains of Aspergillus Niger
}

\author{
Yogesh Khairnarr, Vamsi Krishna $\mathrm{K}_{5}{ }^{2}$, Amol Boraste ${ }^{3}$, Nikhil Gupta ${ }^{5}$, Soham Trivedi ${ }^{4}$, Prasad Patil ${ }^{6}$, \\ Girish Gupta ${ }^{7}$, Mayank Gupta ${ }^{5}$, Amol Jhadav ${ }^{1}$, Adarsh Mujapara ${ }^{8}$, Joshi B. ${ }^{9},{ }^{3}$ Mishra D. ${ }^{10}$ \\ ${ }^{1}$ Padmashree Dr. D.Y. Patil University, Navi Mumbai, 400614, India \\ ${ }^{2}$ Rai foundations College CBD Belapur Navi Mumbai \\ ${ }^{3}$ S.V.P.M. College of Pharmacy, Baramati, Pune \\ ${ }^{4}$ V.V.P. Engineering College, Rajkot, Gujrat \\ ${ }^{5}$ Sindhu Mahavidyalaya Panchpaoli Nagpur \\ ${ }^{6}$ Dr. D. Y. Patil ACS College, Pimpri, Pune \\ ${ }^{7}$ S.D.S.M. College Palghar, Mumbai \\ ${ }^{8}$ Sir PP Institute of Science, Bhavnagar, Gujrat \\ ${ }^{9}$ Rural College of Pharmacy, D.S Road, Bevanahalli, Banglore \\ ${ }^{10}$ Senior Research Coordinator, Reliable analytical laboratory, Thane
}

\begin{abstract}
Fermentation technology plays a very important role in the field of Biotechnology. Production of various enzymes, antibiotics, single cell proteins, various food products, etc is carried out in a vessel called as the bioreactor which is the seed of fermentation technology. The project includes study of Pectinase production using submerged fermentation and various parameters like different substrate, different strains and fermentation time to obtain the maximum yield of Pectinase. To achieve this various research is being conducted. Aspergillus Niger species was being used in this work for the production of Pectinase.
\end{abstract}

\begin{abstract}
Introduction
Pectinase are enzymes which degrade pectic substances and are of great importance to the food industry. These enzymes are used to facilitate extraction, filtration and clarification and to increases yields in the production of fruit juices and beverages [2]. Pectinase is extensively used in food processing industry, souring of cotton, degumming of plant fibers, waste water treatment, vegetables oil extractions, tea and coffee fermentation, bleaching of paper, in the alcoholic beverage [3]. These enzymes classified according to the criteria whether Pectinase act by tranelimination or hydrolysis or whether cleavage is random. They are pectin esterase (PE), depolymerizing enzymes and propectinase [3].Microbial sources of polygalacturonase More than 30 different genera of bacteria, yeasts and moulds have been used for the production of PGases. However, Erwinia, Bacillus, Saccharomyces, Kluyveromyces, Aspergillus, Penicillium, Fusarium and Rhizopus have been the genera most frequently studied in the last 15 years, with strains of Aspergillus, Penicillium and Erwinia mainly used for enzyme production studies [5]. Selection of the microbial source for PGase production depends on several features, such as the type of culture (solid-state or submerged fermentation), number and type of the produced Pectinase, $\mathrm{pH}$ and thermal stability of the enzymes, and genotypic characteristic of the strain [5]. Industrial production of this enzyme is carried out using mostly Aspergillus Niger.
\end{abstract}

\section{Materials and Method}

Various parameters were studied during the work. Fungal species have an ability of using any kind of nutrient source for its growth. Culture conditions: The culture was obtained from NCIM 543 Pune and MTCC 1344 in lyophilized form and the culture was grown on PDA and subcultured for 30 days.

Screening of Strains: Screening methodology was used in this study. It was formulated the pectinase screening agar medium (PSAM): 1 $\mathrm{gm}$ pectin, $0.3 \mathrm{gm}$ Diammonium orthophosphate;0.2 gm; $\mathrm{KH}_{2} \mathrm{PO}_{4} ; 0.3 \mathrm{gm} \mathrm{K} \mathrm{HPO}_{4}, 0.01 \mathrm{gm} \mathrm{MgSO}_{4}$ and $2.5 \mathrm{gm}$ agar(for $100 \mathrm{ml}$ ) The initial $\mathrm{pH}$ of medium was adjusted to 4.5. This medium was sterilized and distributed aseptically in Petri dishes. The Petri dishes containing PSAM were inoculated and incubated at $37^{\circ} \mathrm{C}$ for $24 \mathrm{hrs}$. At the end of the incubation period, plates were stain with $50 \mathrm{mM}$ iodine for result.

Substrate sources: A microorganism requires a lot amount of carbohydrate source for enzyme productions. Two substrates sources were used for the productions of Pectinase. 1. Pectin, 2. Wheat bran

Pectin as substrate source was actually the chemical source available at various laboratories. Wheat bran as substrate was agriculture waste which was used as major substrate source for the Pectinase productions.

\section{Shake flask Studies}

Pectin as substrate: The medium was composed of $\mathrm{NaNO}_{3} 2 \%$, K2HPO4 $1 \%$, MgSO 4 $5 \%$, KCl $5 \%$, FeSO4 $0.001 \%$, Pectin $15 \%$. The initial $\mathrm{pH}$ of medium was adjusted to 3.8. In 250 $\mathrm{ml}$ flasks $200 \mathrm{ml}$ of the medium was added and inoculated with spore suspensions. Two flasks for each strain and one flask for control. The strain culture were incubated in a rotary shaker incubated (150 rpm) at $30^{\circ} \mathrm{C}$ for 3 days (72 hrs). After every 24 hrs (till $72 \mathrm{hrs}$ ) $10 \mathrm{ml}$ broth was separated by filtrations and culture filtrate used as source of crude enzyme [10]. 
Wheat Bran: The media was composed of $50 \mathrm{ml}$ mineral solution, $40 \mathrm{gm}$ wheat bran, $150 \mathrm{ml}$ distilled water. In $250 \mathrm{ml}$ flasks $200 \mathrm{ml}$ of the medium was added and inoculated with spore suspensions. Two flasks for each strain and one flask for control. The strain culture were incubated in a rotary shaker incubated (150 rpm) at $30^{\circ} \mathrm{C}$ for 3 days (72 hrs). After every $24 \mathrm{hrs}$ (till $72 \mathrm{hrs}) 10 \mathrm{ml}$ broth was separated by filtrations and culture filtrate used as source of crude enzyme

Table 1- Mineral Solution Composition

\begin{tabular}{|l|l|}
\hline Ingredients & Amount (gm /l) \\
\hline $\mathrm{KH}_{2} \mathrm{PO}_{4}$ & 0.2 \\
\hline $\mathrm{MgSO}_{4}$ & 0.1 \\
\hline$\left(\mathrm{NH}_{4}\right)_{2} \mathrm{SO}_{4}$ & 0.4 \\
\hline $\mathrm{FeSO}_{4}$ & 0.08 \\
\hline $\mathrm{MnSO}_{4}$ & 0.008 \\
\hline $\mathrm{ZnSO}_{4}$ & 0.006 \\
\hline
\end{tabular}

\section{Downstream processing:}

I) Partial Purification: Culture filtrate was cooled to $4^{0} \mathrm{C}$ for $30 \mathrm{~min}$. Treated with three volumes of chilled ethanol and allowed to stand for $15 \mathrm{~min}$. The precipitation obtain by centrifugation (5000 rpm for $10 \mathrm{~min}$ ) was dissolved in distilled water and used for further investigation.

II) Extraction of crude enzyme: culture filtrate centrifuged at $10000 \mathrm{rpm}$ for $10 \mathrm{~min}$ at $27^{\circ} \mathrm{C}$ Supernatant was taken in test tube. Supernatant is used for further investigation.

Enzyme Assay: The Standard protocol of Sigma Quality Control Department was used for the enzyme Assay. $0.5 \%$ pectin solution, $50 \mathrm{mM}$ iodine with $200 \mathrm{mM}$ potassium iodide, $1 \mathrm{M}$ sodium carbonate, $2 \mathrm{M}$ sulfuric acid, $100 \mathrm{mM}$ sodium thiosulfate, $1 \%$ starch indicator, Pectinase solution.

\section{Table 2-}

\begin{tabular}{|l|l|l|}
\hline Regent & Test & Blank \\
\hline Pectin solution & 4.90 & 5.00 \\
\hline Pectinase & 0.10 & ---- \\
\hline $\mathrm{I}_{2} / \mathrm{KI}$ & 5.0 & 5.0 \\
\hline $\mathrm{Na}_{2} \mathrm{CO}_{3}$ & 1.0 & 1.0 \\
\hline $\mathrm{H}_{2} \mathrm{SO}_{4}$ & 2.0 & 2.0 \\
\hline
\end{tabular}

Mix by swirling the mixture. Titrated the Test and Blank with reagent $\mathrm{Na}_{2} \mathrm{~S}_{2} \mathrm{O}_{3}$ until it is light yellow. Then added 1 drop of Starch indicator and continuously titrate it with reagent $\mathrm{Na}_{2} \mathrm{~S}_{2} \mathrm{O}_{3}$ until solution becomes colourless [12].

\section{Calculation:}

Units $/ \mathrm{ml}$ enzyme $=(1)(100)(\mathrm{ml}$ of regent $\mathrm{E}$ for blank $-\mathrm{ml}$ of regent $\mathrm{E}$ for test $)(\mathrm{df})$ (5) (0.1) (2)

Ammonium Sulfate Fractionation: Various percentage of Ammonium Sulfate was being used for the precipitation of the enzyme sample. $10 \mathrm{ml}$ crude enzyme solution (Cell free filtrate) was taken in centrifuged tube. Then added (40\%, $50 \%, 65 \%$, and 70\%) ammonium sulphate to enzyme solution. Keep at $4^{0} \mathrm{C}$ for overnight. Then centrifuged at $12000 \mathrm{~g}$ for 15 mins Pellet was dissolved using sodium acetate buffer. Precipitated enzyme was purified by using ion exchange column chromatography

Ion Exchange Chromatography: The basic principle behind the use of the column preparation was to treat the enzyme sample with various concentrations of salt solutions. This process actually helped with the removal of various bound and unbound proteins were removed. DEAE Cellulose was used for column Preparation. The protocol for the column preparation is as follows: $2.5 \mathrm{gm}$ of DEAE cellulose was prepared in $12 \mathrm{ml}$ of $0.05 \mathrm{M}$ Tris $\mathrm{HCl}$ and the beads were allowed to swell for 30 minutes. The bottom of the syringe was packed with glass wool. The matrix was poured into syringe column to the level of $7.5 \mathrm{~cm}$ and allowed to settle. The $\mathrm{pH}$ of column was maintained at 8.0. Column was always filled with buffer to avoid from drying the matrix. The column was used again for the separation of the proteins.

\section{Observation and Results}

Screening of Strains: Aspergillus Niger (NCIM 543) demonstrated a large zone of hydrolysis around the large colony on pectin agar medium. The zone of clearance was seen, degradation was evidenced by a clear zone around fugal growth (Diameter of zone of clearance was 4.3 $\mathrm{mm}$ ) Aspergillus Niger (MTCC 1344) demonstrated a large zone of hydrolysis around the large colony on pectin agar medium. The zone of clearance was seen, degradation was evidenced by a clear zone around fugal growth. (Diameter of zone of clearance was $4.5 \mathrm{~mm}$ )

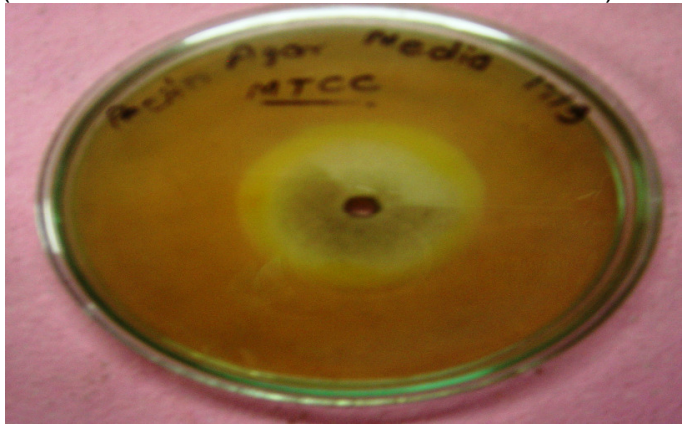

Fig. 1- Aspergillus Niger MTCC (1344)

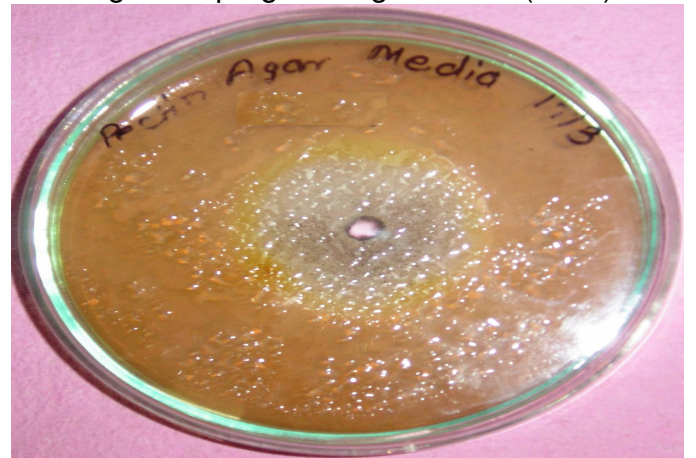

Fig. 2- Aspergillus Niger NCIM (543) 
Enzymatic Assay

Partially Purified enzyme (Pectin)

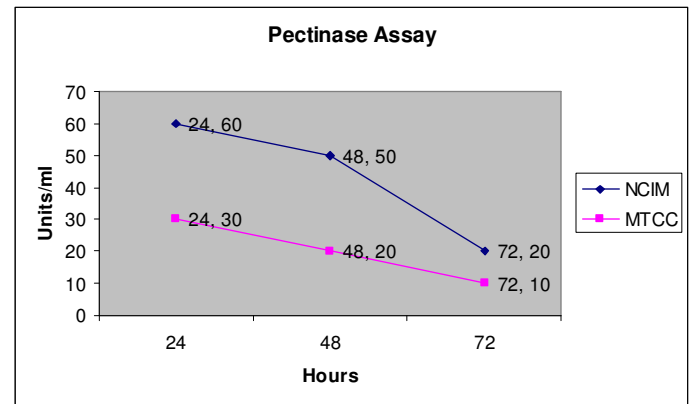

Fig. 3- Graphical Comparison of NCIM and MTCC (Pectin)

The strain from NCIM shows maximum activity as compared to strain from MTCC when pectin is used as substrate. The enzyme used for enzymatic assay was partially purified. The enzyme Pectinase showed maximum activity after 24 hours of incubation and later on started depleting when the incubation time was increased.

Crude enzyme (Pectin)

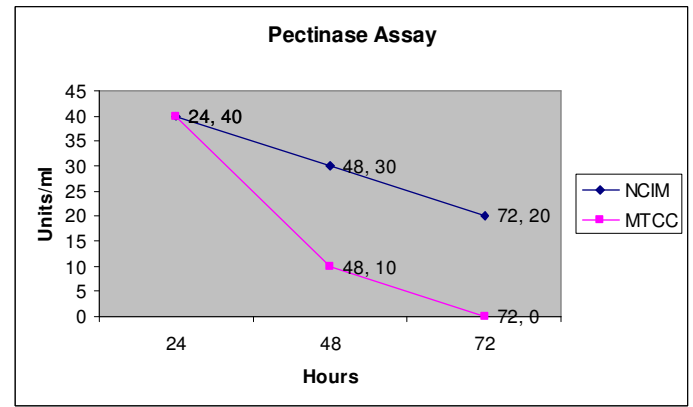

Fig. 4- Graphical Comparison of NCIM and MTCC (Pectin)

The strain from NCIM and strain from MTCC shows similar activity when pectin is used as substrate. The enzyme used for enzymatic assay was crude enzyme .The enzyme Pectinase showed maximum activity after 24 hours of incubation and later on started depleting when the incubation time was increased.

Partially Purified enzyme (Wheat bran):

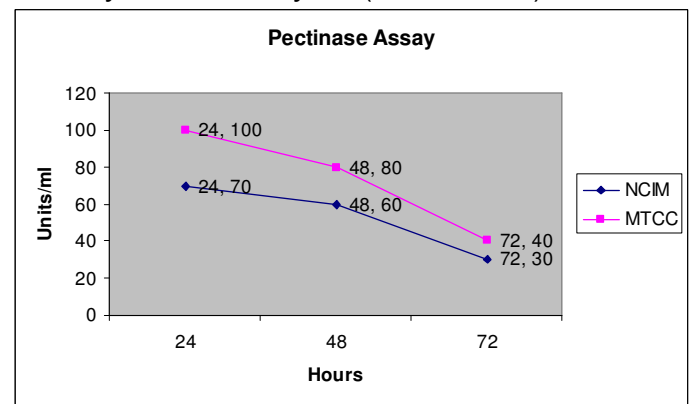

Fig. 5- Graphical Comparison of NCIM and MTCC (Wheat bran)
The strain from MTCC shows maximum activity as compared to strain from NCIM when wheat bran is used as substrate. The enzyme used for enzymatic assay was partially purified. The enzyme Pectinase showed maximum activity after 24 hours of incubation and later on started depleting when the incubation time was increased.

\section{Crude enzyme (Wheat bran)}

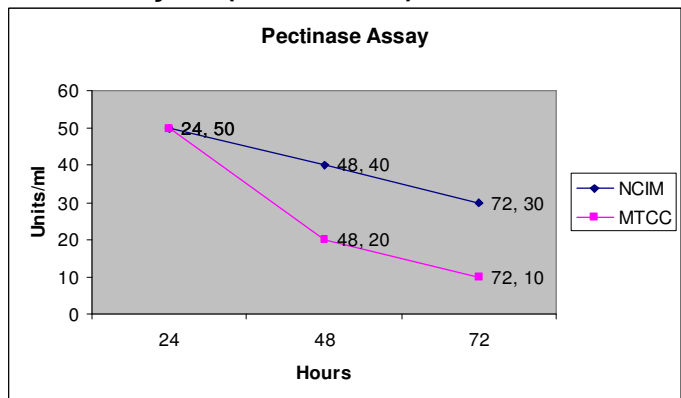

Fig. 6- Graphical Comparison of NCIM and MTCC (Wheat bran)

The strain from NCIM and strain from MTCC shows similar activity when wheat bran is used as substrate. The enzyme used for enzymatic assay was crude enzyme. The enzyme Pectinase showed maximum activity after 24 hours of incubation and later on started depleting when the incubation time was increased.

Ammonium Sulfate Fractionation Result: It is often used to remove proteins other than the one being purified. The technique involves adding increasing concentrations of ammonium sulfate to the protein solution and centrifuging out the precipitated material in certain concentration ranges. Highest degree of precipitations was achieved by $65 \%$ concentration of ammonium sulphate. Ammonium sulfate fractionation; proteins can be further purified by the sequential application of chromatography.

\section{Ion Exchange Results}

The ammonium sulfate Fractionation samples were transferred on the column. The Column was then treated with five different solutions as follows:

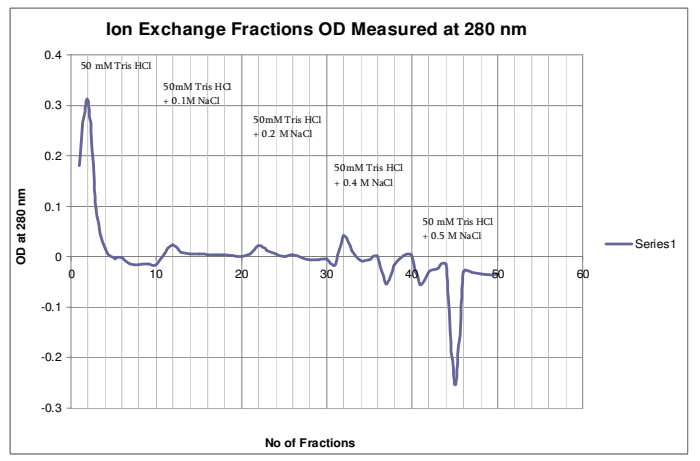

Fig. 7- 


\begin{tabular}{|c|c|c|c|c|c|}
\hline \multicolumn{6}{|c|}{$\begin{array}{c}\text { Tris - HCL }(0.05 \mathrm{M}) \\
0.1 \mathrm{M} \mathrm{NaCl}+\text { Tris - HCl } \\
0.2 \mathrm{M} \mathrm{NaCl}+\text { Tris - HCl } \\
0.4 \mathrm{M} \mathrm{NaCl}+\text { Tris - HCl } \\
0.5 \mathrm{M} \mathrm{NaCl}+\text { Tris - HCl }\end{array}$} \\
\hline Sample & $0.05 \mathrm{M}$ & $0.05 \mathrm{M}$ & $0.05 \mathrm{M}$ & $0.05 \mathrm{M}$ & $0.05 \mathrm{M}$ \\
\hline & Tris HCl & $\begin{array}{l}\text { Tris HII } \\
\text { No.1M } \\
\text { NaCl }\end{array}$ & $\begin{array}{l}\text { Tris } 2 \mathrm{Cl} \\
+0.2 \mathrm{M} \\
\mathrm{NaCC}\end{array}$ & $\begin{array}{l}\text { Tris HCl+ } \\
0.4 \mathrm{MNaCl}\end{array}$ & $\begin{array}{l}\text { Tris } \\
0.5 \mathrm{M} \mathrm{IaCl}\end{array}$ \\
\hline 1 & 0.1802 & 0.0056 & 0.0056 & -0.0172 & -0.057 \\
\hline 2 & 0.3118 & 0.024 & 0.021 & 0.042 & -0.0302 \\
\hline 3 & 0.0966 & 0.0082 & 0.0126 & 0.0133 & 0.0245 \\
\hline 4 & 0.0161 & 0.006 & 0.0059 & -0.0074 & -0.0148 \\
\hline 5 & -0.0015 & 0.0062 & 0.0007 & -0.0049 & -0.254 \\
\hline 6 & -0.002 & 0.0042 & 0.0042 & 0.0006 & -0.0286 \\
\hline & -0.0148 & 0.0037 & -0.0026 & -0.055 & -0.031 \\
\hline 8 & -0.0168 & 0.0035 & -0.0051 & -0.0161 & -0.035 \\
\hline 9 & -0.0145 & 0.002 & -0.006 & 0.0021 & -0.0372 \\
\hline 10 & -0.016 & 0 & -0.0031 & 0.001 & -0.0342 \\
\hline
\end{tabular}

\section{SDS PAGE:}

The Samples with the highest O.D. readings were used for inoculating on the SDS -PAGE. The Molecular weight of the Protein was found to be $40 \mathrm{KDa}$. The samples used for the inoculation on the PAGE are mentioned below:

Lane 1: Molecular Marker

Lane 2: $0.05 \mathrm{M}$ Tris $\mathrm{HCl}+0.1 \mathrm{M} \mathrm{NaCl}$ (Fraction No.2) Lane 3: $0.05 \mathrm{M}$ Tris $\mathrm{HCl}+0.2 \mathrm{M} \mathrm{NaCl}$ (Fraction No.2) Lane 4: $0.05 \mathrm{M}$ Tris $\mathrm{HCl}+0.4 \mathrm{M} \mathrm{NaCl}$ (Fraction No.2) Lane 5: $0.05 \mathrm{M}$ Tris $\mathrm{HCl}+0.5 \mathrm{M} \mathrm{NaCl}$ (Fraction No.5) Lane 6: $0.05 \mathrm{M}$ Tris $\mathrm{HCl}+0.2 \mathrm{M} \mathrm{NaCl}$ (Fraction No.3) Lane 7: $0.05 \mathrm{M}$ Tris $\mathrm{HCl}+0.4 \mathrm{M} \mathrm{NaCl}$ (Fraction No.3)

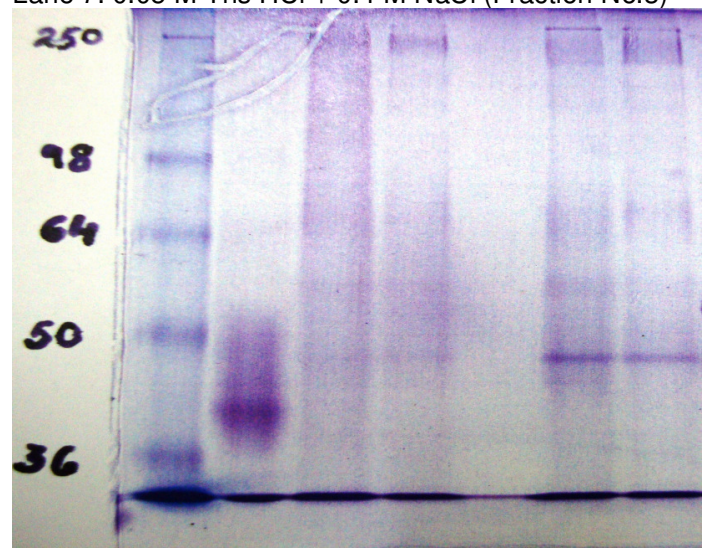

Fig. 8- Lane 3, 4 and 5 did not show any bands. Lane 6 and 7 were showing light bands that could be other proteins. Lane 2 showed only one band which had molecular weight between $36-50$ Kda. According to studies [14] and result which was obtained from SDS-PAGE that shows the molecular weight of Pectinase is $40 \mathrm{Kda}$.

\section{Discussion}

Microbial Pectinase can be stated as the most important enzyme for the juice industry. Although Pectinase production is an inherent property of most all organisms, only those microbes that produce a substantial amount of extracellular Pectinase are of industrial importance and have been exploited commercially. Of these, strains of Aspergillus species dominate the industrial sector. The production parameters were first studied at shakes flask level and Parameters were studied is different carbon source, different strain of aspergillus Niger, $\mathrm{pH}$. Optimization of cultural condition for $\mathrm{pH}$ and growth were studied for $72 \mathrm{hrs}$, along with the optimization of production parameters. Aspergillus Niger showed maximum growth at $\mathrm{pH} 3.8$ as compared its growth at other various respective $\mathrm{pH}$ range varying from $\mathrm{pH} 3.8$ to $\mathrm{pH}$ 5. During growth studies, the maximum biomass or cell mass was obtained in between $24 \mathrm{hrs}$ to $48 \mathrm{hrs}$. The production of Pectinase from Aspergillus Niger is greatly influenced by initial culture $\mathrm{pH}$. The optimum $\mathrm{pH}$ for production of Pectinase by A.niger was 3.8. In the present study, however, the most significant level of growth and production of Pectinase were supported by $\mathrm{pH}$ ranging between 3.8 to 5 . The entire fermentation process was carried out at room temperature $\left(30^{\circ} \mathrm{C}\right)$. Earlier studies have stated that the optimum temperature for the production of Pectinase from A.niger was found out to be $28^{\circ} \mathrm{C}$ [2] and $30^{\circ} \mathrm{C}$ [1] According to studies and result which was obtained from SDS-PAGE that shows the molecular weight of Pectinase is $40 \mathrm{Kda}$.

\section{References}

[1] Sayem S. M. A., Alam M. J., Hoq M. M. (2006) proceedings- Pakistan Academy of Sciences, 43 (4), 257-262.

[2] Rombouts F.M., Voragen A.G.J., Searlevan Leeuwen M.F., Geraeds C.C.J.M., Schols H.A., Pilnik W. (1988) Carbohydrate Polymers, 9, 25-47.

[3] Yugandhar N.M., Ravi Kumar D.V.R., Prasanthi V., Kiran Kumar N. and Sri Rami Reddy D. (2008) Research Journal of Microbiology, 3 (1), 9-16.

[4] Kertesz Z.I. (1955) Methods in ezymology, 1, 162-164.

[5] Ernesto Favela-Torres, Tania VolkeSepúlveda and Gustavo ViniegraGonzález (2006) Food Technol. Biotechnol., 44 (2) 221-227.

[6] Maldeno M.C. and Strasser De Saad A.M. (1998) J.Ind. Micro I.Biotechnol., 20, 3438.

[7] Experimental Biosciences: Introductory laboratory - Bios 211.

[8] William V. Dashek and Jessie A. Micales: Assay and Purification of EnzymesOxalate Decarboxylase. Methods in Plant Biochemistry and Molecular Biology, (1997), ISBN: 1-8493-9480-5.

[9] Scott E. Baker (2006) Medical Mycology, 44, s1, 17-21. 
[10] Gretty K. Villena and Marcel GutiérrezCorrea (2007) Electronic Journal of Biotechnology, 10, 1.

[11] Rashmi R., Siddalinga Murthy K. R., Sneha G., Shabana S., Syama A. and Radhika V. S. (2008) Journal of Applied Biosciences, 9(1), 378 - 384.

[12] Sigma Quality control test procedure: Enzymatic assay of Pectinase (1997) EC 3.2.1.15, 1-4.

[13] Hossam S. Hamdy (2005) Annals of Microbiology, 55 (3), 205-211.

[14] Kalyani Mondal, Payal Mehta and Munishwar N. Gupta (2004) Protein Expression and Purification, 33, 104109. 